\title{
THE NEW INTERNATIONAL ARCHITECTURE
}

\author{
RUDI DORNBUSCH $\dagger$
}

\author{
CESIFO WORKING PAPER NO. 769 \\ CATEGORY 6: MONETARY POLICY AND INTERNATIONAL FINANCE \\ SEPTEMBER 2002
}
An electronic version of the paper may be downloaded
- from the SSRN website: www.SSRN.com
- from the CESifo website: www.CESifo.de




\section{THE NEW INTERNATIONAL ARCHITECTURE}

\section{Foreword}

In 1998 Rüdiger Dornbusch gave the Munich Lectures in Economics entitled "International Financial Crises". The CES Academic Council awarded him the prize and title "Distinguished CES Fellow" for his outstanding work on the monetary theory of foreign trade.

Rüdiger Dornbusch passed away on July 25, 2002, before he was able to finalize the manuscript of his most stimulating and thought-provoking lectures. The manuscript was scheduled to appear in the CESifo book series with MIT Press. This working paper contains the introduction which was distributed at the lectures. CES would like to make this document available to the scientific community.

There is a video presentation of the lectures on the CES website (www.CESifo.de), and a leaflet is also available with the introductory speech by Stanley Fisher.

Munich, September 2002

Hans-Werner Sinn

JEL Classification: F3, E5, F2

Keywords: International Finance, Financial Crises, IMF 
Rudi Dornbusch

MIT

In the aftermath of every crisis, whether war or currency collapses, there is a soul-searching effort to build a better world. Just such an effort, short lived and without leaving a trace, got underway after the Mexican debacle. Another one, more substantial because of Japan's role in it and the extent of Asia's disaster, is being conducted just now. This is a great occasion for bad ideas, or just impractical ones, to gain currency. Just in case, let us set out here where the crises come from and what is the most effective way of dealing with them.

In the past, balance of payments crises were predominantly current account crises and the story would go somewhat like this. A country had a large trade deficit from overvaluation or over-expansion or from both. There was some debt service and there was not enough money around. Reserves would already have run off, new loans were not to be gotten. Sooner or later a devaluation and/or recession would rectify the situation and, for habitual offenders, they would soon be back in the same situation. More often than not, the external deficit was just the counterpart of a budget deficit, happy twins of overspending supplemented with fixed rates to contain inflation and thus give the public a boon, too, by rising real wages in dollars. Social peace means high wages in dollars, big government and full employment, while external balance means just that you can pay your way. Obviously the two goals can come in conflict and reality, meaning the external constraint, always wins out, sooner or later. When it comes to the showdown, spending needs to be cut and wages in dollars have to fall; austerity is the answer.

More recent crises, starting with the early 1990s in Latin America, Mexico in 1994-95 and now Asia and Russia are fundamentally different in that balance sheet issues are entirely central to the fact and surely the propagation of the crisis. These crises have to do with an inability to roll an existing debt, a liquidation scramble and a resulting currency collapse. ${ }^{1}$ Balance sheet crises by their nature have far more leverage both in collapsing a country's financial structure and hence its economy but also in spreading contamination. They are

\footnotetext{
${ }^{1}$ The term liquidation scramble comes from the 1930s where it was used in the context of the liquidity of the national balance sheet at a time of financial crisis.
} 
capital market crises. If capital market crises have more oomph once they happen; meltdown is the best description. Their resolution is also more complicated and certainly more costly.

Designing an international system that is less crisis-prone must address the central issue of capital market crises - unsound finance, which translates into national balance sheet vulnerability. Vulnerability is the key word; risk is another way of looking at it. No two crises are quite alike but they all have in common that without significant vulnerability, currency and financial collapse is very unlikely.

\section{Interpreting the Asian Crisis:}

The Asian crisis is easily interpreted as a capital market crisis - not a crisis of capitalism, as the Japanese officials like to argue. Central to that interpretation, several ingredients:

- In the balance sheets of the financial system and large corporations there is systematic mismatching of maturities. They borrowed short either because it is cheaper or because nobody is willing to lend to them at long maturities. On the asset side they are funding with these loans long-term investments such as real estate development, corporate capital formation or even infrastructure. Not a good idea to fund highways with overnight money. In referring to loans we already make implicitly the point that equity might have been a much better vehicle. The resulting vulnerability takes the form of liquidity risk - the sudden inability to roll over debts.

- The second source of vulnerability was mismatching of denominations. Asia borrowed in dollars or yen to fund investments with payoffs in local currency. As a result, balance sheets were exposed to the risk of currency movements. A major currency depreciation would carry the risk of bankrupting a large part of the financial system or their loan customers.

- The third source of vulnerability was market risk - borrowing to carry assets that are exposed to large fluctuations in their capital value: stocks, commodities, foreign exchange or high risk instruments such as Brady bonds. Korean financial institutions, for example, had taken a large position in Russian bonds and Brazilian Brady bonds. When their prices fell sharply the balance sheets of the Koreans had instantly a huge hole.

- The next source of vulnerability is national credit risk. Because the various banks and companies had collectively assumed a large risk position, the national credit rating had 
been put at risk with spillover effects to anyone in case of a liquidation scramble both in terms of the capital value of their assets and the access to alternative sources of credit.

In a well supervised financial system - say the US or the UK today - all this could not have happened. But, of course, it is routine in Japan, Russia or anywhere in Latin America. The negligent or deliberate lack of regulation, supervision and transparency then comes in as an explanation for the fragile financial structure. This is further complicated by a key mistake on the part of central banks: gambling away the reserves. Central banks in both Thailand and Korea went out of their way to take gambles in forward markets until their reserves were gone; they went out of their way to cheat on the numbers. Any sense of sleaze or lack of transparency was certainly reinforced by the active cooperation of bureaucrats who have worked untiringly, taking bribes, overlooking flagrant risk taking and adding to the vulnerability by misrepresenting central bank assets. All this would not be possible without active help from politicians. In this last sense, the Asian crisis is also a crisis of sleazy governments.

Of course, vulnerability alone is not enough to have an accident. Something has to happen to bring the fragility into play. Here external factors play a role. It would be wrong to place the entire blame on mismanagement in the Asian economies themselves. Two critical complications came from the outside. But that is by way of explanation - vulnerability has to do with just such possibilities! First, Japan went tanked and the resulting deterioration in Asian economies' trade environment accounts for some of the problem and the shadow following over Asian investment opportunities for more. Second, and perhaps more important, movements in the dollar/yen rate moved sharply, thereby leaving the dollar peggers high and dry. That, too, is only by way of explanation. As the Figure shows, the yen had been as low as 80 yen/\$ only a few years ago and not the 200 in the mid-1980s. The idea that the yen could depreciate was not a brand new concept that risktakers could be excused for not ever having imagined. Those who enjoyed the stark yen overvaluation with its resulting export competitiveness for dollar peggers surely must have understood that the pendulum swings wide both ways. 


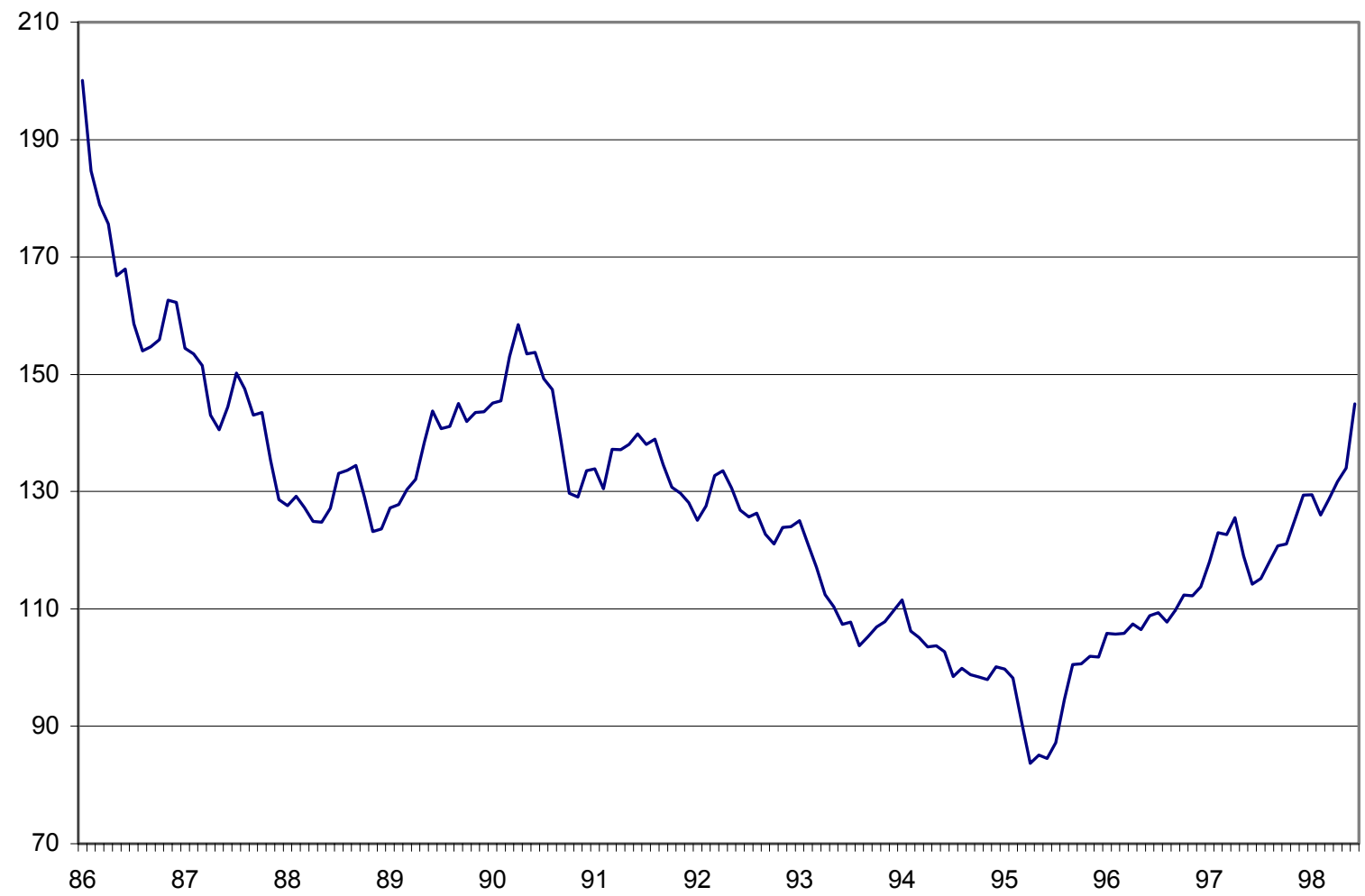

The summary of factors can be customized to country experiences. What makes the Philippines special? They came late to the game, took little of the external money and hence had less of a balance sheet problem and less of a meltdown - more nearly the old style of crisis. Or Malaysia, banking problems yes but much less of an external debt problem because financing took the form of direct investment. Or Korea, where the aggravation of circumstances lies in the dysfunctional corporate structure - debt equity ratios of 500 percent plus for the chaebols which control 50 percent of GDP.

If so much is made of vulnerability now, how come nothing had gone wrong in the past? The answer is that the vulnerability was of very recent vintage -3 or 4 years and not more. Financial opening and hence the very possibility of taking on big risks rather than just bad loans on balance sheets is a matter of the past handful of years, and it takes a while to take on too much and meet a challenge.

The typical scenario, following financial liberalization, is a lending boom funded by offshore borrowing under the cover of a fixed or at least very stable exchange rate. Then, once positions are in place, a disturbance comes on the horizon: domestic investment, notably 
overdone, goes sour, and soon there is a conflict between keeping up the financing by high interest rates or the domestic institutions, banks and companies by low interest rates. If the interest rates are cut, the currency crashes, and if they are raised, the banks and companies crash. In the end - that is the experience - both crash because individual foreign lenders understand that the situation is not viable, returns don't cover the risk and the herd is leaving, and they certainly don't want to be left holding an empty bag.

Vulnerability is in part an objective fact but, just as in the case of bank runs, in part it is in the eyes of the beholder. Contamination therefore is very much part of the play. If the unsustainability of banks or debts is obvious in one place, hard questions will immediately be asked of the next - why not earlier is an interesting question but not relevant at this point. Safety first is the motto of investors when they smell a rat. Thus one vulnerable economy after another tumbles. They did not have to in some immutable statistical sense; it was just that they came under suspicion and the rest is history. Countries that are not vulnerable will also be tested, but they can raise rates and defend their currency, and that quickly becomes a losing game for investors so that they call off the siege, at least until further notice. ${ }^{2}$

Note that neither current account deficits nor budget deficits nor even misaligned exchange rates were part of the balance sheet crisis rendition. In fact, the budget situation in most Asian economies was quite strong, and while exchange rates collapsed, they certainly had not been crassly overvalued as measured by PPP comparisons. (At least that was the case in Asia, though not, of course, in Mexico.) If there was a sign of something amiss, it was in the boom atmosphere that had gotten to construction, consumption and luxury imports. It had all the experience of what in the late 1970s Argentines called plata dulce.

\section{Good Answers:}

The right answer to crisis avoidance is controlling risk. That is done routinely in the domestic financial system of the UK or the US, where the supervisory authorities set and enforce capital standards as well as sophisticated risk measurement. The London authorities go further in imposing differentiated capital requirements for cross-border loans to regions where regulatory or supervisory standards are classified as lax. That is being serious about risk.

\footnotetext{
${ }^{2}$ What is said here of Asia is not the case, however, of Russia or Brazil where budgets are unabashedly large.
} 
How could this be done at the international level? A modest ambition is to create a new culture that focuses on a dissemination of the right thinking. A more ambitious scheme makes support in case of "honest" accidents conditional on compliance with a tightly written and audited scheme.

The starting point of any discussion is that regulatory authorities and supervisors in most countries even today have no clue, nor for that purpose do rating agencies. The appropriate conceptual framework is value at risk, a model-driven estimate of the maximum risk that can be encountered for a particular balance sheet situation over a specified horizon with a stated probability. There are genuine issues of modeling, but there is no issue whatsoever in recognizing that this approach is the right one. Measures such as debt to exports never appear in it, but the ratio of foreign liabilities as a share of total liabilities or the share that is shortdated would just as much as the variability (or probability of an adverse in an event scenario) of asset prices.

If authorities everywhere enforced a culture of risk-oriented evaluation of balance sheets, extreme situations such as those of Asia would just disappear or, at the worst, become a rare species. Perhaps it took a bad experience to understand that the issue is risk, and it is latent in a balance sheet rather than falling from heaven.

The more ambitious step, with an appropriate transition period, is to actually use the regular IMF consultations as the inspection opportunity for the national balance sheet. Countries that would want to have IMF support when in trouble would only qualify if they have, in fact, in the recent past been in compliance with an agreed risk control strategy. This procedure has three advantages. First and foremost, it institutionalizes risk analysis as part of the local supervisory process and as such creates the right culture. Second, it directly lowers risk levels worldwide because countries will be eager to qualify for IMF support in case of honest accidents, which are still possible though less likely. Third, anyone who opts out and wants to run a national gambling house can do so. But it is clear to financial markets that value at risk exceeds internationally acceptable thresholds and, as a result, financing will be hard to get and will be expensive; hence the incentive for rogue countries to join the club.

There is nothing wild-eyed about this proposal, particularly if there is a transition period in which countries can implement what each and every one of them should want to do with the greatest urgency. But that does not mean it will happen at the IMF. The IMF is owned and operated by its board, i.e. representatives of countries like Japan who have no concept of 
sound finance and no willingness to get there soon. The IMF and its board actively enjoys crisis situations, they give the opportunity to wield power, discipline and to grandstand. The notion that anything preemptive is impractical is just far too easily accepted. Accordingly, the immediate interest of what to do with a Russia commands the only attention and how to get a less risky system some 4 or 5 years from now gets none.

\section{Denouncing Some Bad Answers}

Among the bad ideas we should single out some as particularly inadequate. If Goldman goes public to get more firepower, should not the international financial system also get more ammunition? The first is, of course, to provide more money. True, the world financial system today has far more firing power than ever before. Investors have deep pockets and countries cannot be expected to have the resources that can conceivably match what 100 short sellers (including central banks who join the attack, as indeed happens) can put on the table. Making available more rescue money, without anything else, is much the same as better arms for the police - it raises the quality of the shootouts.

It is already the case that the resources used since Mexico exceeds anything one might have imagined at the beginning of the 1990s when the last debt default was still being worked off. How much more and with what success? As we come to the hard core "too large to fail countries" Russia and Brazil - flagrant offenders both in fiscal probity and risk management the numbers become staggering and the violence done in terns of moral hazard unbounded. On the contrary, would it not be a good idea to have a country like Russia do a forced restructuring of maturities to make the point that what seems totally liquid to the lender in fact never is in a crunch. That ought to help mismatching of maturities.

Another terrible idea is capital controls as an alternative to risk management. One might have sympathy with Chilean-style management of inflows, but one has to doubt that countries where inefficient or dishonest administration is the rule (unlike in sweet Chile!) can run a sensible system. More likely it will be a festival of corruption.

An even worse idea, or a non-idea, is an Asian IMF. In the heat of the Thailand crisis, possibly as a very cynical move to push the US Treasury and the IMF into lending and avoid a key contributing role for itself, Japan offered the idea of an Asian IMF and has kept that idea alive to this day. The Asian IMF would pool resources and engage in mutual surveillance in the region. Who can take this seriously? The lead country, Japan, is the most in need of a 
serious financial clean up and the least able to exercise leadership since it is totally stymied by its own problems. Who can see a Korean official telling an Indonesian that they need to pull their socks up and can't be quite so corrupt? If it had gone anywhere, it would have been a festival about restrictions and circumvention and priorities for Japanese banks to get paid off ahead of the rest. Fortunately and rightly, China stayed away from the whole exercise and it became a flop.

\section{IMF Programs}

Another area of contention is what exactly the IMF should ask of countries on the operating table. In the course of the Asian crises the IMF got a bad name, just as they already had in Latin America in the 1970s. In fact, at the time the IMF had been demonized and it is a bit surprising how it recovered its reputation or at least lost the stigma. Perhaps it was the success of Mexico with ultra-IMF policies.

Many, but most surprisingly, World Bank chief economist Joe Stiglitz has been preaching liberation theology. His message is simply this: the IMF is wrong, high interest rates in the process of stabilization are destructive of sound credit and fiscal restraint is inappropriate since it adds to the recessionary forces. It is not quite clear what the stabilization is all about if it is not tighter money and sounder public finances.

A key point is to separate debt restructuring, which is unpopular but may be inevitable, from high interest rates. To restore financial stability the first point is to put a floor under the currency. If everybody wants to get out because the risk-reward trade-off is too unfavorable, high interest rates are the way to change the equation. A successful stabilization without a hike in rates is like the Chicago Bulls with Michael Jordan - hard to imagine. But that may well leave the issue of bad debts in banks and companies and, as a result, bankruptcy risks. The answer is twofold. First, you can't make omelets without breaking some eggs. Second, debt write-offs may be inevitable; not raising rates is just a bad idea, not a solution.

Mexico, for example, fully implemented a stark US-IMF program of tight money to stabilize the currency and restore confidence. It implemented a tight fiscal policy to restore public credit. Starting off in a near-meltdown situation, confidence returned and within a year the country was in the second leg of a V-shaped recovery. The high interest-rate policy was far from easy, economically and politically, and partial debt relief was provided, at public expense, to various sectors. That pragmatic way of dealing with the high interest-rate issue 
ought to be the example of separating debt issue (dead money) from the problem of reversing capital flight and stabilizing exchange rates. The IMF is unqualifiedly right in its insistence on high rates as the front end of stabilization.

The fiscal issue is in principle more complicated. If a country runs into a currency crisis but actually has no fiscal or debt problem to speak of, why should the budget be tightened? The answer is surely no, there is no reason to take extra pain. Of course, in practice that is not the case. In Asia, financial distress of banks and companies moved a very substantial liability into the budget. As a result there was a major prospective fiscal deterioration and a resulting need to make provision. Taking a 30 percent of GDO hit in public credit needs an offset in the budget to restore confidence of investors. In fact, the less is done on the budget the more will have to be done in interest rates. While in some cases the IMF may have been overzealous, it is doubtful that much of a mistake was made. Public finance has deteriorated massively; calling back mega projects at such a time is totally correct.

It must be very confusing to finance ministers and central bakers around the world to see the World Bank shoot them in the back. Liberation theology is a very bad idea, which makes everybody's task of stabilization even harder than it already is. If somewhere in the Washington institutions there is malpractice, it surely is at the World Bank. 


\section{CESifo Working Paper Series}

(For full list see www.cesifo.de.)

699 Campbell Leith and Jim Malley, Estimated General Equilibrium Models for the Evaluation of Monetary Policy in the US and Europe, April 2002

700 Yin-Wong Cheung and Jude Yuen, Effects of U.S. Inflation on Hong Kong and Singapore, April 2002

701 Henry Tulkens, On Cooperation in Musgravian Models of Externalities within a Federation, April 2002

702 Ralph Chami and Gregory D. Hess, For Better or For Worse? State-Level Marital Formation and Risk Sharing, April 2002

703 Fredrik Andersson and Kai A. Konrad, Human Capital Investment and Globalization in Extortionary States, April 2002

704 Antonis Adam and Thomas Moutos, The Political Economy of EU Enlargement: Or, Why Japan is not a Candidate Country?, April 2002

705 Daniel Gros and Carsten Hefeker, Common Monetary Policy with Asymmetric Shocks, April 2002

706 Dirk Kiesewetter and Rainer Niemann, Neutral and Equitable Taxation of Pensions as Capital Income, April 2002

707 Robert S. Chirinko, Corporate Taxation, Capital Formation, and the Substitution Elasticity between Labor and Capital, April 2002

708 Frode Meland and Gaute Torsvik, Structural Adjustment and Endogenous Worker Recall Probabilities, April 2002

709 Rainer Niemann and Caren Sureth, Taxation under Uncertainty - Problems of Dynamic Programming and Contingent Claims Analysis in Real Option Theory, April 2002

710 Thomas Moutos and William Scarth, Technical Change and Unemployment: Policy Responses and Distributional Considerations, April 2002

711 Günther Rehme, (Re-)Distribution of Personal Incomes, Education and Economic Performance Across Countries, April 2002

712 Thorvaldur Gylfason and Gylfi Zoega, Inequality and Economic Growth: Do Natural Resources Matter?, April 2002

713 Wolfgang Leininger, Contests over Public Goods: Evolutionary Stability and the FreeRider Problem, April 2002

714 Ernst Fehr and Armin Falk, Psychological Foundations of Incentives, April 2002 
715 Giorgio Brunello, Maria Laura Parisi, and Daniela Sonedda, Labor Taxes and Wages: Evidence from Italy, May 2002

716 Marta Aloi and Huw Dixon, Entry Dynamics, Capacity Utilisation and Productivity in a Dynamic Open Economy, May 2002

717 Paolo M. Panteghini, Asymmetric Taxation under Incremental and Sequential Investment, May 2002

718 Ben J. Heijdra, Christian Keuschnigg, and Wilhelm Kohler, Eastern Enlargement of the EU: Jobs, Investment and Welfare in Present Member Countries, May 2002

719 Tapio Palokangas, The Political Economy of Collective Bargaining, May 2002

720 Gilles Saint-Paul, Some Evolutionary Foundations for Price Level Rigidity, May 2002

721 Giorgio Brunello and Daniela Sonedda, Labor Tax Progressivity, Wage Determination, and the Relative Wage Effect, May 2002

722 Eric van Damme, The Dutch UMTS-Auction, May 2002

723 Paolo M. Panteghini, Endogenous Timing and the Taxation of Discrete Investment Choices, May 2002

724 Achim Wambach, Collusion in Beauty Contests, May 2002

725 Dominique Demougin and Claude Fluet, Preponderance of Evidence, May 2002

726 Gilles Saint-Paul, Growth Effects of Non Proprietary Innovation, May 2002

727 Subir Bose, Gerhard O. Orosel, and Lise Vesterlund, Optimal Pricing and Endogenous Herding, May 2002

728 Erik Leertouwer and Jakob de Haan, How to Use Indicators for 'Corporatism' in Empirical Applications, May 2002

729 Matthias Wrede, Small States, Large Unitary States and Federations, May 2002

730 Christian Schultz, Transparency and Tacit Collusion in a Differentiated Market, May 2002

731 Volker Grossmann, Income Inequality, Voting Over the Size of Public Consumption, and Growth, May 2002

$732 \mathrm{Yu}-\mathrm{Fu}$ Chen and Michael Funke, Working Time and Employment under Uncertainty, May 2002

733 Kjell Erik Lommerud, Odd Rune Straume, and Lars Sørgard, Downstream Merger with Oligopolistic Input Suppliers, May 2002 
734 Saku Aura, Does the Balance of Power Within a Family Matter? The Case of the Retirement Equity Act, May 2002

735 Sandro Brusco and Fausto Panunzi, Reallocation of Corporate Resources and Managerial Incentives in Internal Capital Markets, May 2002

736 Stefan Napel and Mika Widgrén, Strategic Power Revisited, May 2002

737 Martin W. Cripps, Godfrey Keller, and Sven Rady, Strategic Experimentation: The Case of Poisson Bandits, May 2002

738 Pierre André Chiappori and Bernard Salanié, Testing Contract Theory: A Survey of Some Recent Work, June 2002

739 Robert J. Gary-Bobo and Sophie Larribeau, A Structural Econometric Model of Price Discrimination in the Mortgage Lending Industry, June 2002

740 Laurent Linnemer, When Backward Integration by a Dominant Firm Improves Welfare, June 2002

741 Gebhard Kirchgässner and Friedrich Schneider, On the Political Economy of Environmental Policy, June 2002

742 Christian Keuschnigg and Soren Bo Nielsen, Start-ups, Venture Capitalits, and the Capital Gains Tax, June 2002

743 Robert Fenge, Silke Uebelmesser, and Martin Werding, Second-best Properties of Implicit Social Security Taxes: Theory and Evidence, June 2002

744 Wendell Fleming and Jerome Stein, Stochastic Optimal Control, International Finance and Debt, June 2002

745 Gene M. Grossman, The Distribution of Talent and the Pattern and Consequences of International Trade, June 2002

746 Oleksiy Ivaschenko, Growth and Inequality: Evidence from Transitional Economies, June 2002

747 Burkhard Heer, Should Unemployment Benefits be Related to Previous Earnings?, July 2002

748 Bas van Aarle, Giovanni Di Bartolomeo, Jacob Engwerda, and Joseph Plasmans, Staying Together or Breaking Apart: Policy-makers' Endogenous Coalitions Formation in the European Economic and Monetary Union, July 2002

749 Hans Gersbach, Democratic Mechanisms: Double Majority Rules and Flexible Agenda Costs, July 2002

750 Bruno S. Frey and Stephan Meier, Pro-Social Behavior, Reciprocity or Both?, July 2002

751 Jonas Agell and Helge Bennmarker, Wage Policy and Endogenous Wage Rigidity: A Representative View From the Inside, July 2002 
752 Edward Castronova, On Virtual Economies, July 2002

753 Rebecca M. Blank, U.S. Welfare Reform: What's Relevant for Europe?, July 2002

754 Ruslan Lukach and Joseph Plasmans, Measuring Knowledge Spillovers Using Patent Citations: Evidence from the Belgian Firm's Data, July 2002

755 Aaron Tornell and Frank Westermann, Boom-Bust Cycles in Middle Income Countries: Facts and Explanation, July 2002

756 Jan K. Brueckner, Internalization of Airport Congestion: A Network Analysis, July 2002

757 Lawrence M. Kahn, The Impact of Wage-Setting Institutions on the Incidence of Public Employment in the OECD: 1960-98, July 2002

758 Sijbren Cnossen, Tax Policy in the European Union, August 2002

759 Chandima Mendis, External Shocks and Banking Crises in Developing Countries: Does the Exchange Rate Regime Matter?, August 2002

760 Bruno S. Frey and Lars P. Feld, Deterrence and Morale in Taxation: An Empirical Analysis, August 2002

761 Lars Calmfors and Åsa Johansson, Nominal Wage Flexibility, Wage Indexation and Monetary Union, August 2002

762 Alexander R. W. Robson and Stergios Skaperdas, Costly Enforcement of Property Rights and the Coase Theorem, August 2002

763 Horst Raff, Preferential Trade Agreements and Tax Competition for Foreign Direct Investment, August 2002

764 Alex Cukierman and V. Anton Muscatelli, Do Central Banks have Precautionary Demands for Expansions and for Price Stability? - Theory and Evidence, August 2002

765 Giovanni Peri, Knowledge Flows and Knowledge Externalities, August 2002

766 Daniel Friedman and Nirvikar Singh, Equilibrium Vengeance, August 2002

767 Sam Bucovetsky and Michael Smart, The Efficiency Consequences of Local Revenue Equalization: Tax Competition and Tax Distortions, August 2002

768 Tapio Palokangas, International Labour Market Regulation and Economic Growth with Creative Destruction, August 2002

769 Rudi Dornbusch, The New International Architecture, September 2002 